\title{
Migrant Workers and Physical Health: An Umbrella Review
}

\author{
Nicola Mucci ${ }^{1, *}$, Veronica Traversini ${ }^{1}$, Gabriele Giorgi ${ }^{2}$, Giacomo Garzaro ${ }^{3}$, Javier Fiz-Perez ${ }^{2}$, \\ Marcello Campagna ${ }^{4}$, Venerando Rapisarda ${ }^{5}$, Eleonora Tommasi ${ }^{1}$, Manfredi Montalti ${ }^{1}$ \\ and Giulio Arcangeli ${ }^{1}$ \\ 1 Department of Experimental and Clinical Medicine, University of Florence, 23 Largo Piero Palagi, \\ I-50139 Florence, Italy; veronica.traversini@unifi.it (V.T.); eleonora.tommasi@unifi.it (E.T.); \\ manfredi.montalti@gmail.com (M.M.); giulio.arcangeli@unifi.it (G.A.) \\ 2 Department of Human Sciences, European University of Rome, 190 Via degli Aldobrandeschi, \\ I-00163 Rome, Italy; gabriele.giorgi@unier.it (G.G.); javier.fizperez@unier.it (J.F.-P.) \\ 3 Department of Public Health Sciences and Pediatrics, University of Turin, 94 Piazza Polonia, \\ I-10126 Turin, Italy; giacomo.garzaro@unito.it \\ 4 Department of Medical Sciences and Public Health, University of Cagliari, SS 554 bivio Sestu, \\ I-09042 Monserrato, Cagliari, Italy; mcampagna@unica.it \\ 5 Department of Clinical and Experimental Medicine, University of Catania, 89 Via Santa Sofia, \\ I-95123 Catania, Italy; vrapisarda@unict.it \\ * Correspondence: nicola.mucci@unifi.it; Tel.: +39-055-417-769
}

Received: 16 November 2018; Accepted: 27 December 2018; Published: 4 January 2019

check for updates

\begin{abstract}
Migrants are mainly employed in "3D jobs" which are dirty, dangerous, and difficult, are characterized by monotony and intense rhythms, and are found in sectors with higher risks such as construction, heavy industry, and agriculture. The aim of this study is to construct a systematic review in order to identify the main occupational risks and occupational diseases of this category. Research included articles published from 2013 to 2018 on major online databases (PubMed, Cochrane Library, and Scopus), which were obtained using a combination of keywords (migrant workers, expatriates, physical health, diseases, illnesses, travel, travelers, work, and occupational medicine). The online search included 1109 references. We excluded 977 studies because they were unrelated to physical health and another 64 due to duplication. There were 68 articles which were analyzed, including six reviews and 62 original articles. The main risks which emerged are developing infectious diseases, metabolic cardiovascular diseases and manifesting a lower quality of life, in particular due to difficulties in accessing local health services. It will be crucial to implement the role of occupational medicine in order to introduce multilevel interventions designed to prevent work-related injuries and illnesses, and to promote healthier working environments.
\end{abstract}

Keywords: migrant workers; expatriates; workplace; physical health; umbrella review; organizational psychology; occupational health

\section{Introduction}

The term "migrant worker" refers to someone who will be employed or has been employed in a paid activity in a state of which he or she is not a citizen. The migration phenomenon is constantly growing; according to the latest United Nations' estimates, the number of migrants has almost doubled, passing from 173 million in 2000 to 258 million in 2017. Over 60\% of migrants live on the Asian continent (about 80 million) and in Europe (about 78 million). Regarding their origin, more than 100 million emigrate from Asia (in particular from India), followed by Europe (61 million), Latin 
America (38 million), and Africa ( 36 million). In $48 \%$ of cases they are female and $74 \%$ are between the ages of 20 and 64 [1].

Currently, the term "migrant" is confused with "expatriate". However, there are some conceptual differences between the two terms: expatriates are people who leave their country of origin to live in another context but do not intend to live abroad forever, maintaining their original nationality for practical reasons [2]. The term "expatriate" is also used for workers from industrialized countries who move abroad for relatively short periods (for example, those engaged in "business travel").

According to research carried out by the Hongkong and Shanghai Banking Corporation (HSBC) in 2008, the expatriate's reasons to move to a particular country are not only economic ones. In fact, in addition to standards of living and salaries, more subjective criteria are considered such as the possibility of socializing with the local population, learning the language, and becoming a part of groups or communities. The most positive impressions have thus been recorded in Germany, followed by Canada and Spain. In these countries, expatriates are used to socializing with the local population and learning the language, joining groups or communities, and even buying properties. Generally, in these countries it is quite easy to integrate, both for expatriates and for family members. When considering the same criteria, China and the United Arab Emirates are countries in which immigrants encounter many difficulties with integration and adaptation to culture [3]. Expatriates can become, if properly integrated, an important resource to promote the sustainable development of the country to which they move. The psychology of sustainability and sustainable development is an innovative field of research, which through the promotion of interpersonal and intrapersonal talents, aims to improve the general quality of life of the community [4].

With regard to employment, immigrants are mainly employed in heavy and risky jobs (the so-called "3D jobs", which are dirty, dangerous, and difficult), namely manual, tiring, and dangerous activities which are characterized by monotony and very intense rhythms. These are often low-income activities which are concentrated in sectors traditionally with higher risks (such as the construction sector, heavy industry, transport, services, and agriculture), employ immigrants for a number of hours' higher work compared to native workers, and often do not correspond to the actual professional profile of the immigrant [5].

The international community has adopted many legal instruments to protect expatriate populations; among these, the documents drawn up during the "International Convention on the Protection of the Rights of All Migrant Workers and Members of Their Families" held in New York in 1990 and the "Protocol to prevent, suppress and punish trafficking in persons" in New York in 2000 stand out for their importance. These tools, along with the rights of migrant workers adopted by the International Labor Organization (ILO), form the foundations of migrants' international legislations [2].

Italy has also acted in this sense with the introduction of the Legislative decree no. 81/2008 and subsequent amendments, in which appears a differentiated and functionalized protection system for this worker category. Migrant workers are included in "priority groups" through which specific strategies on health and safety at work are set up. "Special risks" must be assessed individually and in a reciprocal relationship with each other; in this case, being from other countries is frequently associated with precariousness of work, the use of non-standard contractual forms, stressful situations caused by work contexts (such as one's role in the organization and interpersonal relationships, etc.), work content (including the type of tasks, load, rhythms, and working hours, etc.), and finally age and gender differences, given the high rates of youth and female immigrant employees [6]. The psychology of sustainability is another great opportunity for the protection and development of expatriates in the workplace. Their experiences in their country of origin, re-elaborated according to a positive narrative, enriches the companies of the host country with sustainable and multicultural development $[7,8]$.

The purpose of this study is to construct a systematic review of the scientific literature regarding the health status of migrant workers in order to identify the main occupational risks and diseases that these workers may encounter compared to non-migrant workers, and to highlight some suitable preventive strategies to apply in this area. 


\section{Materials and Methods}

The presentation of this systematic review is in accordance with the PRISMA (Preferred Reporting Items for Systematic Reviews and Meta-Analyses) statement [9].

\subsection{Literature Research}

Research included articles published in the last five years, from 2013 to 2018, on major online databases (PubMed, Cochrane Library, and Scopus). The search strategy used a combination of controlled vocabulary and free-text terms based on the following keywords: migrant workers, expatriates, physical health, diseases, illnesses, travel, travelers, work, and occupational medicine. All research fields were considered. Additionally, we practiced a hand search on reference lists of the selected articles and reviews to carry out a wider analysis.

Two independent reviewers read titles and abstracts of the reports identified by the search strategy. They selected relevant reports according to inclusion and exclusion criteria. Doubts or disagreements were solved by discussion with a third researcher. Finally, they independently screened the corresponding full text to decide on final eligibility.

\subsection{Quality Assessment}

Three different reviewers assessed the methodological quality of the selected studies with specific rating tools in order to assess the risk of bias. We used the International Narrative Systematic Assessment (INSA) method [10] to judge the quality of narrative reviews, the Assessing the Methodological Quality of Systematic Reviews (AMSTAR) method to evaluate systematic reviews, and the Newcastle Ottawa Scale (NOS) method to evaluate cross-sectional, cohort studies, and case control studies [11]. The JADAD scale was applied for randomized clinical trials [12].

\subsection{Eligibility and Inclusion Criteria}

No restrictions were applied based on language or publication type. The studies included in this review focus on the physical health of migrant workers and the main diseases found in this particular category of workers.

\subsection{Exclusion Criteria}

We have excluded reports not related to physical disturbances of migrant workers, articles not related to workers, articles related to mental or stress disorders, and articles about children or children of migrants. We have also excluded reports of lesser academic significance, editorial articles, individual contributions, and purely descriptive studies published in scientific conferences without any quantitative or qualitative inferences.

\section{Results}

The online search included 1109 references from PubMed (591), Scopus (489), and Cochrane Library (29). Of these, 977 were excluded because they were not relevant to the physical health of migrant workers. Of the remaining, 64 items were excluded because they were duplicates. Duplicate publications were carefully eliminated in order not to introduce bias by comparing the authors' names, the issues addressed, workers' destinations, and the results obtained. Overall, 68 studies were included in this review (Figure 1).

Of these, six were reviews and 62 were original articles. Among the original articles, 50 were cross-sectional studies, five were clinical trials, three were cohort studies, two were clinical cases, and two were cases (Table 1). 


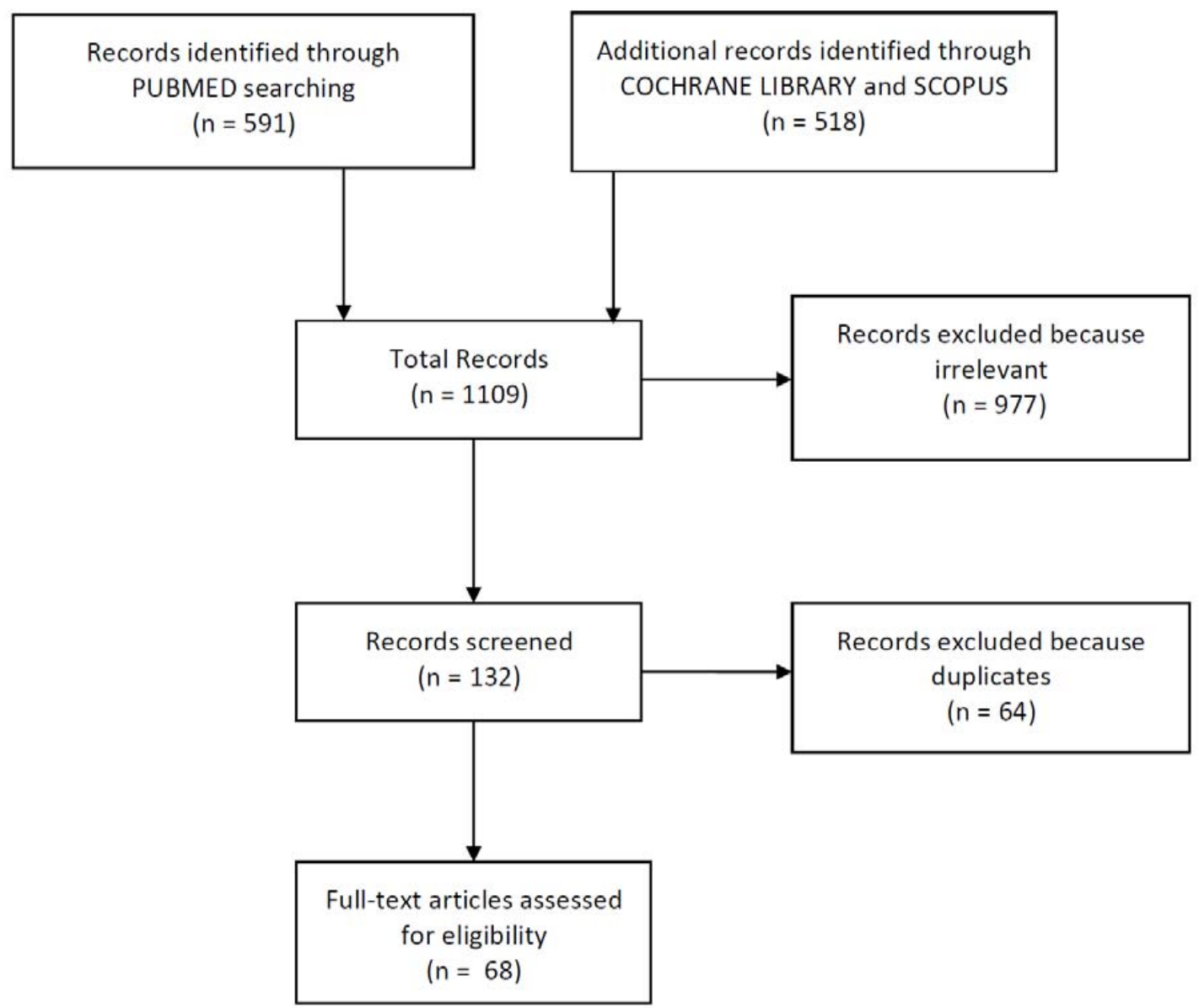

Figure 1. Flow-chart of bibliographic research.

Table 1. Manuscripts included in the review with their related scores.

\begin{tabular}{ccccc}
\hline Authors & $\begin{array}{c}\text { Year of } \\
\text { Publication }\end{array}$ & $\begin{array}{c}\text { Country of } \\
\text { Publication }\end{array}$ & Type of Study & Score \\
\hline Al Hosani F. et al. & 2013 & Arab Emirates & Cross sectional & N.6 \\
\hline Al Rifai R. et al. & 2015 & Japan & Cross sectional & N.8 \\
\hline Anjara S. G. et al. & 2017 & Malesia & Cross sectional & N.7 \\
\hline Arcury T. et al. & 2013 & America & Review & I.4 \\
\hline Banerjee M. et al. & 2015 & India & Cross sectional & N.6 \\
\hline Bener A. & 2017 & Arab Emirates & Cross sectional & N.6 \\
\hline Bhandari P. et al. & 2016 & Korea & Cross sectional & N.7 \\
\hline Bi Y. et al. & 2016 & China & Cross sectional & N.7 \\
\hline Biering K. et al. & 2016 & Denmark & Cross sectional & N.6 \\
\hline Brumitt J. et al. & 2013 & America & Cross sectional & N.6 \\
\hline Castaneda S. et al. & 2015 & America & Cross sectional & N.7 \\
\hline Chen H. et al. & 2016 & China & Cross sectional & N.5 \\
\hline Chen W. et al. & 2016 & China & Trial & J.4 \\
\hline Dafalla A. et al. & 2017 & Arab Emirates & Cross sectional & N.7 \\
\hline Dodd V. et al. & 2016 & America & Cross sectional & N.5 \\
\hline Dodd W. et al. & 2017 & South India & Cross sectional & N.6 \\
\hline & & & & \\
\hline & & & & \\
\hline & & & & \\
\hline
\end{tabular}


Table 1. Cont.

\begin{tabular}{|c|c|c|c|c|}
\hline Authors & $\begin{array}{c}\text { Year of } \\
\text { Publication }\end{array}$ & $\begin{array}{l}\text { Country of } \\
\text { Publication }\end{array}$ & Type of Study & Score \\
\hline Earle-Richardson G. et al. & 2014 & America & Case control & N.6 \\
\hline Fan W. et al. & 2017 & America & Cross sectional & N.7 \\
\hline Fernandez B. & 2018 & Australia & Review & I.5 \\
\hline Fitzgerald S. et al. & 2017 & China & Review & A.7 \\
\hline Fonseca A. et al. & 2017 & Portugal & Cross sectional & N.5 \\
\hline Gao X. F. et al. & 2015 & China & Cross sectional & N.6 \\
\hline Goldenberg S. M. et al. & 2018 & America & Cross sectional & N.5 \\
\hline Habib R. R. et al. & 2016 & Lebanon & Cross sectional & N.6 \\
\hline Hsieh Y. C. et al. & 2016 & America & Cross sectional & N.7 \\
\hline Jensen M. T. et al. & 2015 & Norway & Cross sectional & N.6 \\
\hline Khongthanachayopit S. et al. & 2017 & Thailand & Cross sectional & N.7 \\
\hline Kumparatana P. et al. & 2017 & America & Cross sectional & N.7 \\
\hline Lee W. S. et al. & 2017 & China & Cross sectional & N.7 \\
\hline Lee H. et al. & 2017 & Korea & Trial & J.3 \\
\hline Leng A. et al. & 2016 & China & Cross sectional & N.5 \\
\hline Li W. et al. & 2016 & China & Trial & J.3 \\
\hline Li Y. et al. & 2013 & China & Case report & \\
\hline Lu C. et al. & 2015 & China & Cross sectional & N.7 \\
\hline Lu C. et al. & 2014 & China & Cross sectional & N.7 \\
\hline Lu L. et al. & 2014 & China & Cross sectional & N.7 \\
\hline Mannocci A. et al. & 2016 & Italy & Cohort study & N.7 \\
\hline Martin M. et al. & 2016 & America & Cross sectional & N.7 \\
\hline Mendelsohn J. et al. & 2015 & China & Trial & J.3 \\
\hline Modesti P. et al. & 2017 & Italy & Cross sectional & N.6 \\
\hline Ning C. et al. & 2013 & China & Cohort study & N.8 \\
\hline Norris A. et al. & 2017 & America & Cross sectional & N.7 \\
\hline Perez-Carceles M. D. et al. & 2014 & Spain & Cross sectional & N.7 \\
\hline Pichardo-Geisinger R. et al. & 2013 & America & Cross sectional & N.7 \\
\hline Rodriguez G. et al. & 2016 & America & Cross sectional & N.5 \\
\hline Ronda E. et al. & 2015 & Spain & Cross sectional & N.3 \\
\hline Sabhlok A. et al. & 2015 & India & Review & I. 4 \\
\hline Sanchez J. et al. & 2013 & America & Trial & J.3 \\
\hline Sadarangani S. et al. & 2017 & Malesia & Review & A. 4 \\
\hline Salyer S. J. et al. & 2014 & America & Cross sectional & N.6 \\
\hline Shah S. et al. & 2017 & Arab Emirates & Cross sectional & N.7 \\
\hline Shah S. et al. & 2015 & Arab Emirates & Cross sectional & N.7 \\
\hline Shah S. et al. & 2015 & Arab Emirates & Cross sectional & N.7 \\
\hline Simkhada P. P. et al. & 2017 & UK & Review & I.7 \\
\hline Skogberg N. et al. & 2017 & Finland & Cross sectional & N.7 \\
\hline
\end{tabular}


Table 1. Cont.

\begin{tabular}{ccccc}
\hline Authors & $\begin{array}{c}\text { Year of } \\
\text { Publication }\end{array}$ & $\begin{array}{c}\text { Country of } \\
\text { Publication }\end{array}$ & Type of Study & Score \\
\hline Taha H. A. et al. & 2013 & Arab Emirates & Cross sectional & N.6 \\
\hline Tam W. et al. & 2017 & Malesia & Cross sectional & N.4 \\
\hline Thomas B. et al. & 2014 & South India & Cross sectional & N.7 \\
\hline Urmi A. Z. et al. & 2015 & Bangladesh & Cross sectional & N.7 \\
\hline Varadharajan K. et al. & 2013 & India & Cross sectional & N.7 \\
\hline Vernier M. et al. & 2013 & France & Cohort study & N.5 \\
\hline Wang D et al. & 2015 & China & Case report & \\
\hline Wang P. et al. & 2015 & China & Cross sectional & N.7 \\
\hline Wangroongsarb P. et al. & 2016 & Thailand & Cross sectional & N.7 \\
\hline Xing H. et al. & 2013 & China & Case control & N.6 \\
\hline Yan S. et al. & 2016 & China & Cross sectional & N.6 \\
\hline Yang H. et al. & 2015 & China & Cross sectional & N.7 \\
\hline Yang H. et al. & 2017 & China & Cross sectional & N.7 \\
\hline
\end{tabular}

\subsection{Reviews}

As for the scores of the narrative reviews, the INSA scores showed an average of 5, a median of 4.5 and a modal value of 4 (Table 2), thus indicating the intermediate quality of the studies. The most appropriate methodological narrative review was a study conducted by the United Kingdom in Nepal (INSA = 7). Regarding the scores of the systematic reviews, the AMSTAR scores showed an average and a median of 5.5 .

A review written by Fitzgerald and colleagues takes into account health surveillance and the prevention of occupational accidents among migrant workers in China. The literature review reveals inconsistent injury surveillance among such workers. Although limited, the data suggest that many migrants work in hazardous environments and have injury rates which are disproportionately high, with traumatism occurring, especially in the manufacturing and construction sectors. The authors suggest ways of improving prevention, strengthening the national workplace safety system, and improving workplace safety training and access to appropriate safety devices [13].

Sabhlok and colleagues also focus on the injuries belonging to the particular category of migrant workers, i.e., road builders in the Himalayan territory. The authors point out how these workers, often exploited, develop symptoms of high-altitude work syndrome, including headaches, asthenia, respiratory disorders (like dyspnea, chest pain, and pulmonary edema), and various diseases such as pulmonary fibrosis, chronic bronchitis, and lung cancer, due to exposure to environmental pollutants. These workers are subjected to high levels of stress because they are separated from their families for months and work in inhospitable environments and under extreme physical conditions. All of this results in inappropriate lifestyles such as those involving alcohol abuse and gambling [14].

In a review by Saradangani and colleagues in 2017, significant percentages of malaria, enteric fevers, hepatitis, and tuberculosis were found among expatriate workers in Singapore. The cases of hepatitis E remained low but migrant workers account comprised half the subjects involved. Migrants employed in the construction sector are more likely to contract infections such as dengue, Zika, and chikungunya. Migrant workers in South East Asia appear to be at higher risk than the native population due to a complex interaction of several factors, including a greater prevalence of the disease in their countries of origin, socio-economic factors, conditions of life, and financial, linguistic, and cultural barriers to accessing the health care network. For this reason, receiving countries need to 
reinforce surveillance, to increase preventive measures, and to reduce barriers to access to healthcare for migrant workers [15].

Table 2. Review, trial, case-control, case-report, and cohort studies with their respective diseases and job categories.

\begin{tabular}{|c|c|c|c|c|c|}
\hline Authors & Year & Type of Study & Diseases & Workers' Categories & Score \\
\hline Arcury T. et al. & 2013 & Review & $\begin{array}{l}\text { Injury, illnesses, } \\
\text { pesticides }\end{array}$ & $\begin{array}{l}\text { Agriculture, forestry and } \\
\text { fishing sector workers }\end{array}$ & I.4 \\
\hline Fernandez B. & 2018 & Review & $\begin{array}{c}\text { Pregnancy, injuries, } \\
\text { illnesses }\end{array}$ & Domestic workers & I. 5 \\
\hline Fitzgerald S. et al. & 2017 & Review & Work injuries & $\begin{array}{c}\text { Construction and } \\
\text { manual labor workers; } \\
\text { employees }\end{array}$ & A.7 \\
\hline Sabhlok A et al. & 2015 & Review & $\begin{array}{c}\text { Respiratory diseases, } \\
\text { injuries }\end{array}$ & Road workers & I. 4 \\
\hline Sadarangani S. et al. & 2017 & Review & Infectious diseases & $\begin{array}{l}\text { Employees and domestic } \\
\text { workers }\end{array}$ & A. 4 \\
\hline Simkhada P. P. et al. & 2017 & Review & $\begin{array}{l}\text { Sexual risks, injuries, } \\
\text { alcohol, drugs }\end{array}$ & $\begin{array}{c}\text { Employees and } \\
\text { agricultural workers }\end{array}$ & I.7 \\
\hline Chen W. et al. & 2016 & Trial & $\begin{array}{l}\text { Organic solvent } \\
\text { exposure }\end{array}$ & Employees & $\mathrm{J} .4$ \\
\hline Lee H. et al. & 2017 & Trial & Cardiovascular risk & Employees & J.3 \\
\hline Li W. et al. & 2016 & Trial & Malaria & $\begin{array}{l}\text { Staff members of } \\
\text { company }\end{array}$ & J.3 \\
\hline Mendelsohn J. et al. & 2015 & Trial & Sexual infections & Construction workers & J.3 \\
\hline Sanchez J. et al. & 2013 & Trial & Sexual infections & Agricultural workers & J.3 \\
\hline Xing H. et al. & 2013 & Case control & Quality of life & $\begin{array}{l}\text { Shoe factory, textile, } \\
\text { domestic, construction, } \\
\text { and transport workers }\end{array}$ & N.6 \\
\hline Earle-Richardson G. et al. & 2014 & Case control & Eye irritations & Farm workers & N.6 \\
\hline Li Y. et al. & 2013 & Case report & Malaria & Not specified & Not applicable \\
\hline Wang D. et al. & 2015 & Case report & Infectious diseases & Not specified & Not applicable \\
\hline Vernier M. et al. & 2013 & Cohort study & Hepatitis & Employees & N.5 \\
\hline Ning C. et al. & 2013 & Cohort study & Sexual infections & $\begin{array}{l}\text { Construction and } \\
\text { mining workers }\end{array}$ & N.8 \\
\hline Mannocci A. et al. & 2016 & Cohort study & $\begin{array}{l}\text { Cardiometabolic } \\
\text { diseases }\end{array}$ & Oil and gas workers & N.7 \\
\hline
\end{tabular}

From Simkhada's article, some major risk factors have emerged involving the health of Nepalese workers who move to foreign countries, including sexual habits, type of work, and lifestyles. Sexual behavior can be seen to be influenced by loneliness and desire which emerges when one is separated from partners for long periods, causing risky behavior to be adopted, a condition called "situational disinhibition". In addition, Nepalese migrant workers often deal with dangerous and degrading jobs that local workers do not want to do. The inherent risks put migrant workers at greater risk of workplace accidents and diseases: the most common injuries are cuts, bone fractures, and joint sprains. According to the authors, $82 \%$ of workers in the agricultural and construction sectors reported injuries in the previous 12 months. Furthermore, in the agricultural sector, most Nepalese workers show poor use of personal protective devices [16].

Eight specific professional conditions emerged from Arcury's scientific review which can influence the health status of immigrant workers employed in the agriculture, fisheries, and forestry sectors. These risks include the working environment (i.e., microclimate, plants, and animals), toxic biological substances (allergens and dust), transport, machinery, physical agents (vibrations, noise), chemicals (pesticides, solvents), and, finally, lack of access to medical care [17]. 
Fernandez et al. have examined health needs through an analysis of Ethiopian migrant domestic workers who have access to health care in Lebanon. Health care needs in Lebanon which emerged from the study can be classified into four types of situations: minor illnesses that require only outpatient care, pregnancies, serious illnesses (such as cancer, tuberculosis, or heart problems) and emergencies (including those due to accidents, assaults, or suicide attempts). These inequalities in access to health care are intensified for international migrants, who as a socio-economic group have a less privileged status than citizens. Furthermore, migrants with precarious, temporary, or irregular statuses are more vulnerable and marginalized than regular migrants, as they are often unable to make use of state health services. Health inequalities faced by migrants may be due to a lack of rights based on their migrant status (i.e., they may be migrants with temporary contracts irregular status) and/or due to gender, class, race, and ethnicity barriers [18].

\subsection{Original Articles}

The scores assigned to the transversal articles have an average value of 6.4 , a median and a modal value of 7 (Table 3). This combination represent the good quality of these studies. The studies conducted in Japan and in China obtained the highest values.

Table 3. Cross-sectional studies with their respective diseases and job categories.

\begin{tabular}{|c|c|c|c|c|c|}
\hline Authors & Year & Type of Study & Diseases & Job Categories & Score \\
\hline Al Hosani F. et al. & 2013 & Cross sectional & Tuberculosis & $\begin{array}{c}\text { Office workers, drivers, } \\
\text { domestic workers, food } \\
\text { handlers, etc. }\end{array}$ & N.6 \\
\hline Al Rifai R. et al. & 2015 & Cross sectional & Sexual infections & $\begin{array}{l}\text { Domestic multinational } \\
\text { workers }\end{array}$ & N.8 \\
\hline Anjara S. G. et al. & 2017 & Cross sectional & Lower quality of life & Domestic workers & N.7 \\
\hline Banerjee M. et al. & 2015 & Cross sectional & $\begin{array}{l}\text { Dermatologic and } \\
\text { respiratory problems }\end{array}$ & Construction workers & N.6 \\
\hline Bener A. & 2017 & Cross sectional & $\begin{array}{l}\text { BMI, smoke, pain, } \\
\text { cardiovascular, and } \\
\text { gastrointestinal diseases }\end{array}$ & $\begin{array}{l}\text { Construction and } \\
\text { agricultural workers; drivers }\end{array}$ & N.6 \\
\hline Bhandari P. et al. & 2016 & Cross sectional & $\begin{array}{l}\text { Perceived health, physical } \\
\text { activity }\end{array}$ & $\begin{array}{l}\text { Manual laborers; domestic, } \\
\text { construction, and office } \\
\text { workers; others }\end{array}$ & N.7 \\
\hline Bi Y. et al. & 2016 & Cross sectional & Diabetes & $\begin{array}{l}\text { Manufacturing, } \\
\text { construction, services, and } \\
\text { accommodation workers }\end{array}$ & N.7 \\
\hline Biering K. et al. & 2016 & Cross sectional & Work injuries & Employees & N.6 \\
\hline Brumitt J. et al. & 2013 & Cross sectional & $\begin{array}{l}\text { Tobacco smoke/physical } \\
\text { activity }\end{array}$ & Seasonal farm workers & N.6 \\
\hline Castaneda S. et al. & 2015 & Cross sectional & Cardiovascular diseases & Seasonal farm workers & N.7 \\
\hline Chen H. et al. & 2016 & Cross sectional & Quality of life & $\begin{array}{l}\text { Government and private } \\
\text { enterprise workers; } \\
\text { employees }\end{array}$ & N.5 \\
\hline Dafalla A. et al. & 2017 & Cross sectional & Infectious diseases & $\begin{array}{l}\text { Food handlers, babysitters, } \\
\text { housemaids, drivers }\end{array}$ & N.7 \\
\hline Dodd V. et al. & 2016 & Cross sectional & Oral cancer & Farm workers & N.5 \\
\hline Dodd W. et al. & 2017 & Cross sectional & $\begin{array}{l}\text { Musculoskeletal disorders, } \\
\text { infective diseases, skin } \\
\text { problems }\end{array}$ & $\begin{array}{l}\text { Construction, textile sector, } \\
\text { and manufacturing workers }\end{array}$ & N.6 \\
\hline Fan W. Et al. & 2017 & Cross sectional & Lower quality of life & $\begin{array}{l}\text { Agricultural, textile, and } \\
\text { construction workers }\end{array}$ & N.7 \\
\hline Fonseca A. et al. & 2017 & Cross sectional & $\begin{array}{l}\text { Malaria and endocrine, } \\
\text { metabolic, cardiovascular, } \\
\text { and respiratory diseases }\end{array}$ & $\begin{array}{l}\text { Directors, managers, and } \\
\text { specialists in scientific } \\
\text { activities }\end{array}$ & N.5 \\
\hline
\end{tabular}


Table 3. Cont.

\begin{tabular}{|c|c|c|c|c|c|}
\hline Authors & Year & Type of Study & Diseases & Job Categories & Score \\
\hline Gao X. F. et al. & 2015 & Cross sectional & Tuberculosis & Employees & N.6 \\
\hline Goldenberg S. M. et al. & 2018 & Cross sectional & $\begin{array}{l}\text { Infectious diseases, alcohol } \\
\text { abuse }\end{array}$ & Migrant sex workers & N.5 \\
\hline Habib R. R. et al. & 2016 & Cross sectional & $\begin{array}{l}\text { Respiratory, digestive, and } \\
\text { musculoskeletal disorders }\end{array}$ & Farm workers & N.6 \\
\hline Hsieh Y. C. et al. & 2016 & Cross sectional & $\begin{array}{c}\text { Dermatologic and } \\
\text { musculoskeletal problems }\end{array}$ & Housekeepers & N.7 \\
\hline Jensen M. T. et al. & 2015 & Cross sectional & $\begin{array}{l}\text { Muscle pain, gastric } \\
\text { discomfort }\end{array}$ & Business travelers & N.6 \\
\hline $\begin{array}{c}\text { Khongthanachayopit S. } \\
\text { et al. }\end{array}$ & 2017 & Cross sectional & $\begin{array}{l}\text { Musculoskeletal disorders, } \\
\text { diabetes, hypertension, } \\
\text { allergies }\end{array}$ & $\begin{array}{l}\text { Agriculture sector workers, } \\
\text { employees in } \\
\text { restaurant/factory }\end{array}$ & N.7 \\
\hline Kumparatana P. et al. & 2017 & Cross sectional & Lower health, alcohol & Employees & N.7 \\
\hline Lee W. S. et al. & 2017 & Cross sectional & BMI & Agricultural workers & N.7 \\
\hline Leng A. et al. & 2016 & Cross sectional & Hepatitis B & Rural workers & N.5 \\
\hline Lu C. et al. & 2015 & Cross sectional & Chronic diseases & Factory employees & N.7 \\
\hline Lu C. et al. & 2014 & Cross sectional & BMI & Textile factory employees & N.7 \\
\hline Lu L. et al. & 2014 & Cross sectional & Quality of life & Factory employees & N.7 \\
\hline Martin M. et al. & 2016 & Cross sectional & Cardio-metabolic diseases & $\begin{array}{l}\text { Sales, agricultural, forestry, } \\
\text { and manufacturing workers; } \\
\text { administrators }\end{array}$ & N.7 \\
\hline Modesti P. et al. & 2017 & Cross sectional & Type 2 diabetes & $\begin{array}{l}\text { Textile employees, } \\
\text { managers, students, } \\
\text { housekeepers }\end{array}$ & N.6 \\
\hline Norris A. et al. & 2017 & Cross sectional & HIV & Employees & N.7 \\
\hline $\begin{array}{l}\text { Perez-Carceles M. D. } \\
\text { et al. }\end{array}$ & 2014 & Cross sectional & Hazardous drinking & $\begin{array}{l}\text { Construction industry and } \\
\text { agricultural workers }\end{array}$ & N.7 \\
\hline $\begin{array}{c}\text { Pichardo-Geisinger R. } \\
\text { et al. }\end{array}$ & 2013 & Cross sectional & Dermatologic problems & Manual and poultry workers & N.7 \\
\hline Rodriguez G. et al. & 2016 & Cross sectional & Pain, stress, blood pressure & $\begin{array}{l}\text { Employees in service, } \\
\text { production and office } \\
\text { support }\end{array}$ & N.5 \\
\hline Ronda E. et al. & 2015 & Cross sectional & $\begin{array}{l}\text { Muscle pain, headaches, } \\
\text { gastric discomfort }\end{array}$ & $\begin{array}{l}\text { Employees and domestic } \\
\text { and construction workers }\end{array}$ & N.3 \\
\hline Salyer S. J. et al. & 2014 & Cross sectional & Infectious diseases & $\begin{array}{c}\text { Non-governmental } \\
\text { organization workers }\end{array}$ & N.6 \\
\hline Shah S. et al. & 2017 & Cross sectional & Diabetes & Employees & N.7 \\
\hline Shah S. et al. & 2015 & Cross sectional & $\begin{array}{c}\text { Obesity and cardiovascular } \\
\text { risk }\end{array}$ & Employees & N.7 \\
\hline Shah S. et al. & 2015 & Cross sectional & Hypertension & $\begin{array}{l}\text { Drivers, construction and } \\
\text { agriculture workers, } \\
\text { salesmen, office workers, } \\
\text { tailors, cooks }\end{array}$ & N.7 \\
\hline Skogberg N. et al. & 2017 & Cross sectional & Metabolic syndrome & Employees & N.7 \\
\hline Taha H. A. et al. & 2013 & Cross sectional & Infectious diseases & $\begin{array}{c}\text { Farmers, food handlers, } \\
\text { shepherds, drivers, } \\
\text { housemaids }\end{array}$ & N.6 \\
\hline Tam W. et al. & 2017 & Cross sectional & $\begin{array}{l}\text { Influenza, gastritis, cancer, } \\
\text { accidents }\end{array}$ & Manual workers & N.4 \\
\hline Thomas B. et al. & 2014 & Cross sectional & Chest symptoms & Brick kiln workers & N.7 \\
\hline Urmi A. Z. et al. & 2015 & Cross sectional & Sexual infections & Employees & N.7 \\
\hline Varadharajan K. et al. & 2013 & Cross sectional & Obesity & $\begin{array}{c}\text { Professional, technical, } \\
\text { managerial, sales, services, } \\
\text { and manual labor workers }\end{array}$ & N.7 \\
\hline
\end{tabular}


Table 3. Cont.

\begin{tabular}{|c|c|c|c|c|c|}
\hline Authors & Year & Type of Study & Diseases & Job Categories & Score \\
\hline Wang P. et al. & 2015 & Cross sectional & Lifestyle behaviors & $\begin{array}{c}\text { Service sector and } \\
\text { construction workers; } \\
\text { managers }\end{array}$ & N.7 \\
\hline Wangroongsarb P. et al. & 2016 & Cross sectional & Malaria & $\begin{array}{l}\text { Agricultural, domestic, } \\
\text { factory, and fisheries } \\
\text { workers }\end{array}$ & N.7 \\
\hline Yan S. et al. & 2016 & Cross sectional & Diabetes & Not specified & N.6 \\
\hline Yang H. et al. & 2015 & Cross sectional & BMI & $\begin{array}{l}\text { Manufacturing, } \\
\text { construction, hospitality, } \\
\text { domestic, small business, } \\
\text { and recreation workers }\end{array}$ & N.7 \\
\hline Yang H. et al. & 2017 & Cross sectional & Lifestyle behaviors & $\begin{array}{l}\text { Manufacturing, } \\
\text { construction, hospitality, } \\
\text { domestic, small business, } \\
\text { and recreation workers }\end{array}$ & N.7 \\
\hline
\end{tabular}

The most represented labor categories in these transversal studies were farmers (15 studies; $29 \%$ ), construction workers (12 studies; $23.5 \%$ ), and domestic workers (eight studies; $16 \%$ ).

In these studies, the risk of contracting infectious diseases (12 studies; 23.5\%) and of developing metabolic diseases (11 studies; $20 \%$ ) were examined above all. In addition, eight studies (16\%) highlight the quality of life of migrant workers in a foreign country, six studies (12\%) investigate cardiovascular diseases and about 10 articles $(20 \%)$ deal with different pathologies (including muscular disorders, dermatological disorders, and gastrointestinal and tumor infections).

\subsubsection{Infectious Diseases}

In a study by Dafalla and colleagues, a large sample of expatriates in the United Arab Emirates was examined. The authors found intestinal parasitic infections in 3.3\% of those in the sample and, among these, $96 \%$ were positive for a single parasite, such as Giardia (36\%) and Entamoeba histolytica (31\%). Infections were positively correlated with gender (i.e., with male workers) and with occupational category (i.e., mostly with workers in the food and agriculture industries) [19]. Percentages of higher intestinal infections among migrant workers were also found in a study by Taha and colleagues, with the highest number of infections among farmers, followed by food handlers, shepherds, drivers, and domestic workers. The type of infection is slightly influenced by employment: Trichura was the most common parasite among household workers (29\%), Giardia lamblia was more frequent among drivers $(30 \%)$ and farmers (24\%), and finally Entamoeba histolytica/Escherichia coli was the most represented among pastors (41\%) and food handlers (67\%) [20].

Tuberculosis (TB) is a global public health problem. The results of Al Hosani's study confirm this. The prevalence of active TB among adult expatriates in the United Arab Emirates (about 39 per 100,000) is about 14 times higher than the estimated prevalence of tuberculosis among the native population [21]. According to the study by Gao and colleagues, China, and in particular Sichuan Province, is one of the countries with the highest prevalence of tuberculosis, with 459 cases out of 100,000 migrants. For this reason, the authors investigated the quality of life in migrants suffering from tuberculosis; the results of Quality of Life (QOL) were significantly lower compared to the indigenous Chinese population, especially in the physical, psychological, and environmental domains (with scores of 12.1, 12.9, and 11.7, respectively). Subjects over 50 years of age reported worse scores, such as ones indicating poorer levels of education [22].

In some European countries such as Portugal, there is a growing wave of expatriation and emigration that mainly includes sub-Saharan African destinations such as Angola and Mozambique [23]. This has involved an increasing number of hospitalizations resulting from diagnoses of imported malaria. A study by Fonseca and colleagues aims to understand the 
morbidity of Portuguese expatriates in Africa and the preventive measures applied to malaria through questionnaires administered to 352 workers. The main occupations of these workers were executive managers $(n=77 ; 22 \%)$, and specialists in intellectual and scientific activities. 74 people $(21 \%)$ reported having had at least one new health problem in the previous three months. The most common diseases reported were infections, including pneumonia (15 cases), malaria (12), intestinal infections (eight), typhoid fever (five), and a case of tuberculosis. Because of these, 39 individuals (11\%) reported temporary sick leave, $72(20.5 \%)$ required medical assistance, and $17(5 \%)$ were hospitalized. In $64 \%$ of cases $(n=226)$ psychological disorders were reported such as fatigue, stress, and longing. About $87 \%$ of people used personal anti-mosquito protection measures, namely repellents (55\%), mosquito nets $(25 \%)$, air conditioning $(77 \%)$, domestic insecticides (53\%), and covering arms and legs in the evening (24\%). With regard to chemoprophylaxis, 133 individuals (38\%) reported not having taken it, six (2\%) reported taking mefloquine or atavaquone/proguanil, and $213(60.5 \%)$ reported having taken it only initially [24].

\subsubsection{Cardiovascular and Metabolic Diseases}

Being overweight and suffering from obesity are more common among male migrant workers than the native male population. Cardio-metabolic risk profiles for migrant workers are often not optimal. In Bi's study, for about 50,000 Chinese migrant workers aged between 18 and 59, the prevalence estimates were $27 \%$ for being overweight, $5 \%$ for obesity, $29 \%$ for central obesity, $30.5 \%$ for prediabetes, $5 \%$ for free diabetes, $16 \%$ for hypertension, $34.5 \%$ for dyslipidemia, and $19 \%$ for metabolic syndrome [25].

A study by Varandharajan notes that some specific aspects of migration are associated with being overweight/obesity. In this study, migrant women in rural areas reported a lower frequency of consumption of fruit, eggs, and fish (44\%, 30\%, and $23 \%$, respectively) compared to the native population $(61 \%, 44 \%$, and $36 \%$, respectively). About $15 \%$ of women and $11 \%$ of men were overweight or obese. Factors such as level of education, the type of employment, and the economic status of workers were shown to be directly related to the prevalence of being overweight/obesity. We have seen that gender differences play a fundamental role in moderating the risk of being overweight/obesity among migrants, which is perhaps attributable to different levels of knowledge and information on health, greater access to treatment, and physical activity [26]. Further confirmation may be obtained from Yang H. and colleagues, with $9.9 \%$ of their sample, consisting of migrant workers in China, hypertensive, and $27 \%$ overweight or obese. The authors point out that workers employed in the manufacturing sector reported a less unhealthy lifestyle than those employed in the service sector. Worse life styles were mostly associated with workplaces in confined spaces, with shifts of 8-11 h a day [27].

A study by Shah and colleagues determined the prevalence, associated factors, awareness, treatment, and control of hypertension among 1375 male immigrants from India, Pakistan, and Bangladesh who were residing in the United Arab Emirates. The average age of the participants was 34 years and the overall prevalence of hypertension was 30.5\%; $76 \%$ of those included in the sample who were classified as hypertensive were not aware of its conditions. $48 \%$ of the sample who knew about it reported having used drugs and only $8 \%$ kept their blood pressure under control. Participants were more likely to be overweight or obese and practiced poor physical activity, less than $30 \mathrm{~min}$ a day [28].

Important results were obtained by Castaneda and colleagues, who reported some parameters associated with cardiovascular risk (blood pressure, obesity, diabetes, smoking, and cholesterolemia) among a group of Latino migrants employed in agriculture, and compared these to US seasonal workers: the results showed a greater probability of developing obesity for migrant subjects (OR 2.15), especially in female subjects (OR 3.29), who were more affected by diabetes (OR 4.74) [29].

The aim of Skokberg's research was to compare the prevalence of metabolic syndrome within migrants and within Finnish citizens and evaluate any associated factors. The authors showed 
higher blood sugar levels, and lower HDL levels among Russian, Somali and Kurdish migrants. Furthermore, female migrants have greater abdominal circumference values. Metabolic syndrome was associated with lower levels of education, low physical activity, low fruit and vegetable intake, and unemployment [30].

Diabetes is a serious public health problem among migrants, particularly in Southeast Asia [31]. The prevalence of type 2 diabetes (T2DM) among first generation immigrants in Europe underlines the need for specific health programs for the early diagnosis, treatment, and prevention of this disease [32]. In a study by Modesti and colleagues, out of 1608 Chinese participants, 177 subjects presented T2DM $(11 \%)$, with 119 experiencing a new diagnosis (7.4\%). Among those with diabetes, 58 cases $(32.8 \%)$ were aware of the disease and 46 (79\%) were treated with hypoglycemic drugs. Other important data confirming this has been obtained from a study by Shah et al., in which by analyzing the HbA1C levels of those of the test sample, it was determined that $18.6 \%$ had prediabetes and $10.7 \%$ had type 2 diabetes. The prevalence of prediabetes was $8.5 \%$ for Filipinos, $16.7 \%$ for Arabs, and 30.3\% for South Asians. Similarly, the prevalence of T2DM was 1.7\% for Filipinos, $12.2 \%$ for Arabs, and $16.7 \%$ for South Asians [31]. A study by Yan et al. has reported a prevalence of diabetes of $11.6 \%$ within a sample of 1150 migrants transferred from rural to urban areas of China. The risk increases significantly with age, income, obesity, and hypertension. Based on their SF36 (Medical Outcomes Study 36-Item Short-Form Health Survey) scores, residents aged $>60$ years with diabetes reported greater physical and emotional limitations, more physical pain, and worse physical health than those without diabetes [33].

\subsubsection{Quality of Life}

In a study by Ronda, the pressure and anguish experienced by immigrants due to the precariousness of their working conditions were perceived as having an impact on their state of health and symptoms such as widespread pain, especially muscular pains, headaches, and gastric disorders were reported. Often the use of hypnoinductive drugs is a common mechanism to cope with such inconveniences. The worsening of eating habits, in term of food's quality and quantity, due to a reduced income, is frequent among immigrant workers [34].

Anjara and colleagues found there to be a good quality of life among their study participants. However, more than half of their participants reported feeling stressed and almost $20 \%$ of their participants experienced isolation. Both of these factors are associated with a worse quality of life [35].

Migrants moving from rural to urban areas, particularly employees in small and medium-sized enterprises, are more vulnerable to health risks and report lower Health-Related Quality of Life (HRQOL) score levels [36]. Often these types of companies fail to provide adequate health protection to their migrant workers due to insufficient funds, and management and supervision problems. Studies by $\mathrm{Lu}$ et al. have confirmed this trend by indicating that workers with fixed working hours and higher salaries had higher HRQOL scores. Negative events such as having had a disease in the last two weeks and the need for access to treatment negatively impacted their HRQOL scores $(\beta=-0.78)$, while a work contract, insurance, income, training, access to health care (weekly physical exercise, health check-ups, and use of protective devices) led to an improvement in HRQOL scores ( $\beta=-0.20)$ [37].

Thai researchers [38] evaluated a sample of 600 migrant workers in Thailand to analyze access to and quality of health services, a possible index of discrimination for the non-indigenous population. $63 \%$ of subjects were female, $80 \%$ were employed in the catering sector and $37 \%$ had contracted a disease in the previous 12 months. Of this $37 \%$, only $14 \%$ were able to access local health services (in particular due to economic difficulties, insufficient knowledge of health care systems and distance from hospitals in comparison to residents). Regarding healthcare, 25 expatriate workers in Singapore who were interviewed by Tam and colleagues reported negative experiences, including perceived collusion between doctors and employers, the withholding of medical documentation, insufficient hospitalization or medical leave, and lack of discharge care. Difficulties with reporting work injuries resulted in losses of medical leave wages, an unduly long wait to receiving fair medical assessment and compensation, and the mental stress of waiting to be repatriated [39]. 
One cross-sectional study of over 400 food suppliers who had immigrated to Kazakhstan showed a low overall health status of $46 \%$. Of these, less than $3 \%$ regularly see a doctor and around $10 \%$ have high alcohol consumption rates. Among female subjects, 30\% reported mistreatment and 19\% sexual assaults [40].

A cross-sectional study carried out by Yang H.'s team on over 5000 migrants employed in Shanghai in the last six months showed significant emerging problems regarding their quality of life. Twenty-one percent reported mental disorders such as obsessive-compulsive disorder, anxiety, and hostility, and $63 \%$ reported unhealthy lifestyle habits. In comparison with other participants, men are more likely to be smokers, to consume more alcohol and to eat less fruit and vegetables [41].

Finally, using Health Promoting Behavior (HPB) as a theoretical framework, the aim of Bhandari's study was to describe HPB and identify the predictors of HPB in Nepalese adults working in South Korea. The most frequently practiced health behavior was spiritual growth, followed by interpersonal relationships, nutrition, health responsibility, and stress management. Physical activity was the least practiced health behavior in foreign workers, although most participants were men [42].

\subsubsection{Various Diseases}

In a study by Banerejee et al. which considered a sample of 340 masons, $33.2 \%$ of workers suffered from one or more types of respiratory symptoms, of which 107 (94.6\%) reported that respiratory disorders began after the start of construction work. Among the subjects examined, forty-eight $(14.1 \%)$ suffered from multiple respiratory symptoms, with productive cough and dry cough being the two most common symptoms, present in $27(7.9 \%)$ and $19(5.9 \%)$ patients, respectively. $36.2 \%$ of workers suffered from dermatological problems, of which $116(94.3 \%)$ said that signs of these problems began after the start of the job. Rashes (9.7\%), redness (16.2\%), and skin rash with pruritus $(30.9 \%)$ were the most common dermatological symptoms [43].

The objectives of a study by Perez-Carceles et al. were to identify workers with dangerous alcohol consumption, through AUDIT (Alcohol Use Disorders Identification Test) questionnaires and the carbohydrate-deficient transferrin (CDT) biomarker, in order to ascertain the associated risk factors. The results show that $13 \%$ of 385 migrant workers were positive with AUDIT $>8$ and/or CDT $>2.6$. Being male, working in construction or agriculture, being a resident in Spain for seven years, and sharing a home with friends were found to be the risk factors most associated with increased alcohol consumption [44].

The most common pathologies in Pichardo's cross-sectional study were dermatological diseases, which were present in $52.3 \%$ of the workers in the study sample. Inflammatory skin diseases were present in $28.2 \%$ of workers and pigment diseases in $21.8 \%$ of workers. The most common skin conditions were tinea pedis (37.6\%), fungal infections (31.9\%), scars $(13.7 \%)$, acne (11.8\%) and melasma $(9.3 \%)$. Age, sex, and work (i.e., working on poultry farms) contribute in part to the prevalence of these diseases [45].

Migrant workers in Latin countries may suffer from serious health disparities, including poor oral health. The purpose of research by Dodd and colleagues was to assess risk awareness in this job category, including levels of personal care. Researchers gave specific questionnaires to farm workers in Hillsborough County, Florida. Among the subjects examined, $53.7 \%$ of the respondents were female; the average age for males and females was 38.7 and 39.2 respectively. Among the participants, $6.7 \%$ had never attended school; the knowledge of risk factors, signs, and symptoms of oral cancer were low, with a lack of attention to prevention [46].

Agricultural workers involved in a study by Brumitt et al. completed a questionnaire on health and levels of physical activity. Of the subjects examined, $58.2 \%$ reported doing exercises during the week, $16 \%$ reported physical activity for $3 \mathrm{~h}$ or more a week, $17 \%$ reported smoking, and $10 \%$ reported chewing tobacco. Tobacco use is higher among individuals who do not practice sport [47]. 


\subsection{Trial}

With regard to the selected trials, the methodological quality was fair, with a score greater than three for all the studies. Two of these experimental studies dealt with the prevalence of the risks of sexually transmitted diseases and risky behaviors among expatriate workers.

In the first study [48], the experimenters designed a three-phase trial. In Phase 1, data from a survey given to 1871 workers belonging to 18 building sites, and the results of tests on HIV and sexually transmitted diseases were collected. In Phase 2, three educational interventions were implemented in the community (the first intervention consisted of distribution of educational leaflets; the second, educational posters and a series of instructional videos; and the third, consultations with groups and individual counseling sessions). Finally, in Phase 3, three and six month follow-up interviews were conducted to evaluate the impact of these interventions on risky behavior. When considering the results obtained, it was observed that men were twice as likely to participate in intervention activities $(\mathrm{OR}=2.2 ; p=0.036)$. There were no differences in participation among younger workers ( $<30$ years) and older workers $(\mathrm{OR}=1.1 ; p=0.766)$. More educated workers had higher participation rates than less educated workers $(\mathrm{OR}=1.9 ; p=0.01)$.

In the second trial concerning sexually transmitted diseases [49], a community-based participatory research project, "Project Salud", was presented with the aim of involving the Latin American community in Florida in the prevention of HIV. The main objective of "Project Salud" was to compare and evaluate the effectiveness of two different methods: the so-called Adapted Stage-Enhanced Motivational Interviewing (A-SEMI) method, which was divided into four group sessions to prevent HIV and encourage safe sexual behavior, and the Health Promotion Condition (HPC) method, which was aimed at promoting public health strategies such as hygiene and first aid. The 278 participants were randomly assigned to A-SEMI or HPC. Both interventions consisted of four interactive sessions of approximately $2 \mathrm{~h}$ which were structurally equivalent, included the administration of questionnaires, and were succeeded by a follow-up after 3-9 months. The A-SEMI participants had a greater knowledge of HIV ( $p=0.009)$, and perceived fewer obstacles to condom use $(p<0.001)$, which they use more consistently $(p<0.001)$.

Chen W. and colleagues, however, have emphasized that migrant workers are at greater risk of developing occupational health risks due to incorrect behavior, such as low use of personal protective equipment (PPE). For this reason, they proposed a protocol of an experimental study to be carried out on migrant workers in 60 small-to-medium enterprises in China. The subjects were to be divided into two groups (intervention and control) and the results analyzed after zero, three and six months in order to verify the use of PPE and expand the knowledge of workers on specific risks [50].

The purpose of the experimentation of Lee $\mathrm{H}$. et al. was to examine the effects of a standardized walking program (ST) compared to an enhanced ambulation program (ET) with reference to the main cardiovascular parameters among 132 Chinese migrant workers in Korea, without contraindications to physical activity. Both groups had to reach monthly goals; the ET group received text messages to encourage walking and movement. After 12-24 weeks, there was a significant decrease in risk at 10 years for cardiovascular disease (CVD), blood pressure, fasting glucose, BMI and abdominal circumference in both groups [51].

$\mathrm{Li}$ and colleagues have tried to distribute knowledge on the risk of contracting malaria among 1441 Chinese workers who have migrated to Niger for work, through the use of chat and social networks. The participants initially completed a questionnaire on their knowledge of the disease, then were randomly divided into an experimental group or a control. The first group was constantly sent specific messages regarding the prevention of and therapy against malaria, while the second group was given more general information. After four months, the participants again completed the questionnaire. In the first questionnaire the percentages on experience and knowledge stood at $58-60 \%$, while after four months they passed to $70 \%$. Improvement was mainly found in the experimental group compared to the control $(p<0.01)$, and a decrease in malaria diagnoses was recorded, going from $23.72 \%$ to $15.40 \%$ during the experimentation period [52]. 


\section{Discussion}

The issue of attention to the protection of health and safety in the workplace of migrant workers is very relevant, especially for the occupational physician. In fact, it is important to underline the importance of ethical, professional, scientific, and legislative motivations that require the occupational physician to protect the most vulnerable workers, because of possible social and health consequences.

Our review has highlighted some specific risk factors present in this area which are deserving of adequate consideration, in particular for the prevention of repercussions on work activity.

Among these, infectious diseases feature strongly in the etiology of the main disorders of migrant workers. Infections are one of the major causes of mortality and morbidity as regards public health, particularly in developing countries [20,53]. Most migrant workers such as farmers, drivers, and waiters come from regions endemic to intestinal infections, characterized by modest socioeconomic levels and poor access to care [54]. The spread of pathogens has been closely linked to educational, environmental, and health conditions, as well as socio-economic status and access to medical care. Some categories of workers are considered to be most at risk, such as cooks, waiters, and agricultural producers; poor hygiene conditions and inadequate knowledge about food storage can be sources of pathogens and may be involved in the transmission of infections to local communities and consequently to business travelers or tourism [55].

Infections such as tuberculosis and malaria are still global public health problems $[20,56]$; according to the latest WHO estimates, tuberculosis is the ninth-leading cause of death in all its forms, with 1.3 million TB deaths in 2016 and 10.4 million people infected, of whom 65\% were male, and with $56 \%$ of cases coming from countries such as China, the Philippines, and Pakistan [57].

Despite significant efforts and resources dedicated to the control of these diseases, they remain a difficult challenge to face due to the increase in mobility between countries, and the difficulties of accessing treatment for some populations and for cases resistant to treatment [58,59].

Emerging infections, such as pathologies not present in a territory but of import due to migrations and higher mobility among workers (for example, cases of dengue and Zika from South America or avian influenza from China), must be taken into account for the purposes of proper health surveillance $[60,61]$.

Moreover, migrant workers exhibit demographic characteristics that may put them at high risk for heterosexual HIV transmission, such as unstable family and work situations, ease of access to high-risk (including commercial) sex, and lack of access to HIV treatment and prevention programs [62-64]. Rural residence, longer durations of migrant work and independence, physical isolation, alcohol use, and human rights violations are associated with testing positive; being female, higher levels of education, policy reforms, and workplace interventions are negatively associated with testing positive $[65,66]$.

Many studies report a higher prevalence of obesity and cardiovascular diseases associated with migrants due to environmental factors and changes in lifestyles $[67,68]$. One of the possible explanations for the greater prevalence of metabolic syndrome among migrants is the rapid transition from developing countries to Western countries; rapid changes in environmental factors and changes in lifestyles, such as greater sedentary habits and more consumption of energy foods, worsen the cardiovascular profiles of migrants $[69,70]$. Migration from rural areas to urban areas has in fact been associated with incorrect lifestyles and behavior patterns, with an increase in the consumption of polyunsaturated fats and a reduction in the consumption of saturated fats, complex carbohydrates, and fibers, as well as poor physical activity, having ben observed [27,71]. Also important is the role of particularly stressful jobs carried out by expatriate workers, including long shifts and night shifts that can alter biological cycles such as glucose and lipid metabolism [72].

These studies support the idea of the "Healthy Migrant Effect", as reported in 2009, which highlights how migrants experience a decay in their health status which is proportional to the length of their stay in Western countries [73]; longer durations of stay have been associated with an increase in cardiovascular risks, including being overweight, obesity, and hypertension [74]. This effect is related 
proportionally to the country of origin, the reasons for the transfer to another country, the lifestyles adopted, and the determinants examined, such as the relationship between ischemic diseases, diabetes, and number of years of stay of migrants in Denmark [73,75].

The work conditions, climate, and the plans and personal expectations of each individual, together with a host of other factors, combine to form a model of alcohol consumption that may reflect the habits of the country of origin, or even involve increased drinking. The relation between substance abuse and migration is complex. There seems to be a multifactorial relation in which biological, psychological, cultural, and social factors intervene. Some authors have associated hazardous alcohol consumption with the type of work [76,77]. Construction and agriculture, both open to inclement weather, traditionally offer hard work conditions, and ingestion of alcohol before beginning work is a common habit [44]. Occupational health services are one of the pillars for conducting early interventions. For prevention, in fact, work is the ideal place, given the homogeneity of the population concerned, the free access to all employees, and the possibility of follow-up activity.

According to the Italian Workers Compensation Authority (INAIL), in 2016 work accidents in Italy involving foreign workers amounted to 61 thousand (15\% of the total), of which 45 thousand occurred to non-EU citizens and about 16 thousand to EU citizens; events occurred in the industrial sector in $87 \%$ of cases, with another $6 \%$ in agriculture, and $29 \%$ involving female subjects [78].

The data available to us through this review of the literature confirm this trend, as many studies highlight the greater risk of accidents being incurred for migrant workers, as they often work in hazardous environments without safety devices available, especially in the productive sectors and building [79]. Construction workers belong to one of the occupational categories most exposed to various risks in the workplace, including those which are physical, chemical, biological, and ergonomic $[44,77]$. This category of work is more likely to incur trauma, (even that which is fatal), and to induce the development of respiratory diseases such as chronic obstructive pulmonary disease, asthma, silicosis, and dermatological diseases [80]. The authors of these studies suggest some preventive strategies that can be applied in order to prevent and reduce (even fatal) accidents: for example, it is necessary to identify areas with higher risk (e.g., construction, manufacturing, and mining) to improve the training of personnel in the field of safety, to strengthen the use of adequate equipment often not used, and to establish or strengthen national surveillance systems.

From our review, it may be concluded that another particularly risky sector is agriculture. Migrant farmers are among the most marginalized of job classes, being often very poor, without legal protection, and having residence in inadequate facilities [81]. Workers employed in the seasonal migrant agricultural sector are exposed to climatic conditions with high temperatures, to chemicals and pesticides that can lead to dermatological diseases and respiratory diseases, and to incongruous postures and repetitive movements which result in musculoskeletal disorders and sometimes fatal traumatic injuries [82-84]. Housing conditions including poorly ventilated housing, poor hygienic conditions, and humidity and mildew favor the onset of respiratory diseases such as pneumonia and asthma, and infectious diseases [81,85].

Furthermore, a lack of knowledge on occupational diseases combined with poor use of safety devices exposes these workers to a greater risk of having accidents and developing occupational diseases (mainly allergic symptoms) [86].

Through our review, we have highlighted that the quality of life of migrant workers is lower than that of native populations. Migrant workers are a vulnerable population group in urban areas $[87,88]$. These people have, in most cases, lower education levels, lower income, heavier workloads, and longer working hours, and are more likely to live in more crowded housing compared to local residents [36]. Health-related quality of life has become an important target in the medical area, with consideration given to treatment outcome assessments, health economics evaluations, and assessing the effects of health education. HRQOL has been widely applied in epidemiological studies. However, this methodological approach has rarely been used among migrant workers without specific illnesses. New-generation migrant workers experience significant impairment in HRQOL compared with urban 
workers in terms of psychological and environmental domains, and in general health. Lower HRQOL in migrant workers may be explained by their poor social support and living and working conditions [89]. Foreign workers may undergo difficulty in adapting to their new positions; they may experience more work-related stress such as inadequate rest due to overtime work and inadequate medical and social security coverage provided by their employers [90]. Social relationships and networks that exist in the countryside are difficult to achieve in urban areas because of the distances and surroundings, leading to ever-decreasing social support [91,92]. To reduce work-related stress and foster interpersonal relationships among migrants, the psychology of sustainable development may be drawn upon, as it promotes greater connection with nature and empathy. Expats who settle in new social and work environments become an irreplaceable resource for the entire community [93].

Through this work, it has been made clear how the occupational physician has before him or her the commitment to protect the health of the immigrant worker, a person with specific needs but who must be guaranteed levels of protection similar to those belonging to native workers.

The physician will have to identify the worker's origin and his or her personal history in order to identify socio-cultural differences, difficulties in linguistic comprehension, and compliance with prevention interventions. Health surveillance will therefore be essential through a careful medical history (i.e., a physiological, pathological, and working history) and a precise objective examination, which is correlated by laboratory and diagnostic examinations and targeted on a case-by-case basis. Information-training courses for workers will be fundamental for prevention purposes. In Italian Law their content is understandable and occurs by verifying the comprehension of the language (Article 36 and 37 of Legislative Decree no. 106/09) to avoid security issues, management of emergencies, and understanding of procedures.

Our scientific review and included studies have some limitations as a whole. First, most of the studies are cross-sectional rather than intervention or efficacy evaluations, which would be of particular interest to the physician given that they could aid in understanding the determinants of occupational diseases and the setting up of appropriate interventions. We have included articles published in the last five years, from 2013 to 2018, as studies before this period were not very relevant to our research field. In fact, in recent years we have observed greater interest in and attention on the part of researchers to this issue, which has been directly proportional to the exponential growth of migratory flows worldwide.

Studies are often being conducted outside the European context on small specific communities with difficulties of extrapolation to our context; in most cases, results on migrant workers have been compared with data on native workers, not allowing for the adequate characterization of the risk. Overall, the quality of the cross-sectional studies was of average value due to the frequent use of subjective assessment tools, such as questionnaires administered to the sample which were not always standardized, and to the lack of description of the characteristics of those who decided not to submit the questionnaire (the so-called "non-respondents"). In addition, the quality of the trials was average; the value assigned, in almost all cases, did not reach the maximum score, due to a lack of specificity of randomization or double/single-blind study, or to the failure to describe cases lost to the follow-up.

Finally, it was a very complex process to compare very different studies according to the type of sector of work of those within the samples in question (from the "business travelers" to the domestic workers or farmers), to gender differences that also affect the type of work, and to environmental contexts totally different for each culture, religion, and legislation (for example, the differences between South America, the United Arab Emirates, and South East Asia).

\section{Conclusions}

In light of the trend of increases in migratory flows and the increase in the prevalence of occupational accidents and illnesses among foreign workers caused by unfavorable working conditions, health professionals must direct their attention and their commitment to the protection of this worker category. The data in the literature and the technical-legislative tools to deal with this 
issue are well available today; through these data and through appropriate preventive interventions, physicians can guarantee the targeted management of this vulnerable population, especially in the most dangerous sectors.

Author Contributions: Conceptualization, N.M., V.T., and G.G. (Gabriele Giorgi); Methodology, N.M., V.T., and G.G. (Gabriele Giorgi); Formal analysis, N.M., V.T., and G.G. (Gabriele Giorgi); Writing-original draft preparation, N.M., V.T., and G.G. (Gabriele Giorgi); Writing—review and editing, G.G. (Giacomo Garzaro), J.F.-P., M.C., and V.T.; Linguistic revision: E.T. and M.M.; Supervision, N.M., M.C., and V.R.; Project administration, N.M. and G.A.

Funding: This research received no external funding.

Conflicts of Interest: The authors declare no conflict of interest.

\section{References}

1. International Migration Report 2017 (Highlights). Available online: https:/ /www.un.org/development/ desa/publications/international-migration-report-2017.html (accessed on 30 October 2018).

2. Just Landed. Available online: https://www.justlanded.com/italiano/Common/Footer/Espatriati/ Statistiche-e-caratteristiche (accessed on 30 October 2018).

3. HSBC Expat Explorer. Available online: https://www.expatexplorer.hsbc.com (accessed on 30 October 2018).

4. Di Fabio, A.; Rosen, M.A. Opening the Black Box of Psychological Processes in the Science of Sustainable Development: A New Frontier. Eur. J. Sustain. Dev. Res. 2018, 2, 47. [CrossRef]

5. Porru, S.; Arici, C. Gruppi vulnerabili-Migranti. In Trattato di Medicina del Lavoro, 1st ed.; Alessio, L., Franco, G., Tomei, F., Eds.; Piccin-Nuova Libraria: Padova, Italy, 2015; Volume II, pp. 1327-1336. ISBN 978-88-299-2708-1.

6. Di Carluccio, C. Salute e sicurezza sul lavoro del lavoratore migrante tra conferme e sviluppi. Diritto della Sicurezza sul Lavoro 2017, 1, 45-74.

7. Di Fabio, A. The Psychology of Sustainability and Sustainable Development for Well-Being in Organizations. Front. Psychol. 2017, 8, 1534. [CrossRef] [PubMed]

8. Di Fabio, A. Positive Healthy Organizations: Promoting well-being, meaningfulness, and sustainability in organizations. Front. Psychol. 2017, 8, 1938. [CrossRef] [PubMed]

9. Moher, D.; Liberati, A.; Tetzlaff, J.; Altman, D.G. PRISMA Group. Preferred reporting items for systematic reviews and meta-analyses: The PRISMA statement. PLoS Med. 2009, 6. [CrossRef] [PubMed]

10. La Torre, G.; Backhaus, I.; Mannocci, A. Rating for narrative reviews: Concept and development of the International Narrative Systematic Assessment tool. Sens. Sci. 2015, 2, 31-35. [CrossRef]

11. Wells, G.A.; Shea, B.; O'Connel, D. The Newcastle-Ottawa Scale (NOS) for Assessing the Quality of Non-Randomized Studies in Meta-Analyses. 2009. Available online: http:/ / wwwohrica/programs/clinical_ epidemiology / oxford (accessed on 30 October 2018).

12. Jadad, A.R.; Moore, R.A.; Carroll, D.; Jenkinson, C.; Reynolds, D.J.; Gavaghan, D.J.; McQuay, H.J. Assessing the quality of reports of randomized clinical trials: Is blinding necessary? Control. Clin. Trials 1996, 17, 1-12. [CrossRef]

13. Fitzgerald, S.; Chen, X.; Qu, H.; Sheff, M.G. Occupational injury among migrant workers in China: A systematic review. Inj. Prev. 2013, 19, 348-354. [CrossRef]

14. Sabhlok, A.; Cheung, H.; Mishra, Y. Narratives of health and well-being: Migrant road workers in the upper Himalayas. Econ. Polit. Wkly. 2015, 50, 51.

15. Saradangani, S.P.; Lim, P.L.; Vasoo, S. Infectious diseases and migrant worker health in Singapore: A receiving country's perspective. J. Travel. Med. 2017, 24. [CrossRef]

16. Simkhada, P.P.; Regmi, P.R.; Van Teijlingen, E.; Aryal, N. Identifying the gaps in Nepalese migrant workers' health and well-being: A review of the literature. J. Travel. Med. 2017, 24. [CrossRef] [PubMed]

17. Arcury, T.A.; Grzywacz, J.G.; Sidebottom, J.; Wiggins, M.F. Overview of immigrant worker occupational health and safety for the agriculture, forestry, and fishing (AgFF) sector in the southeastern United States. Am. J. Ind. Med. 2013, 8, 911-924. [CrossRef] [PubMed]

18. Fernandez, B. Health inequities faced by Ethiopian migrant domestic workers in Lebanon. Health Place 2018, 50, 154-161. [CrossRef] [PubMed] 
19. Dafalla, A.I.A.; Almuhairi, S.A.S.O.; Al Hosani, M.H.J.; Abuodeh, R.O.; El Bakri, A. Intestinal parasitic infections among expatriate workers in various occupations in Sharjah, United Arab Emirates. Rev. Inst. Med. Trop. Sao Paulo 2017, 59, 82. [CrossRef] [PubMed]

20. Taha, H.A.; Soliman, M.I.; Banjar, S.A. Intestinal parasitic infections among expatriate workers in Al-Madina Al-Munawarah, Kingdom of Saudi Arabia. Trop. Biomed. 2013, 1, 78-88.

21. Al Hosani, F.I.; Yahia, G.A. Prevalence of pulmonary tuberculosis among expatriates subjected to medical visa screening in Abu Dhabi, United Arab Emirates. J. Epidemiol. Glob. Health 2013, 1, 23-30. [CrossRef]

22. Gao, X.F.; Rao, Y. Quality of life of a migrant population with tuberculosis in West China. Int. J. Tuberc. Lung Dis. 2015, 2, 223-230. [CrossRef]

23. Fonseca, A.G.; Dias, S.S.; Baptista, J.L.; Torgal, J. The burden of imported malaria in Portugal 2003 to 2012. J. Travel. Med. 2014, 2009-2011. [CrossRef]

24. Fonseca, A.G.; Dias, S.S.; Baptista, J.L.; Torgal, J. Portuguese expatriates' health in Angola and Mozambique-A cross-sectional study: Increasing awareness and need for more surveillance. J. Travel. Med. 2017, 4. [CrossRef]

25. Bi, Y.; Wang, L.; Xu, Y.; Jiang, Y.; He, J.; Zhang, M.; Li, Y.; Xu, M.; Lu, J.; Wang, T.; et al. Diabetes-related metabolic risk factors in internal migrant workers in China: A national surveillance study. Lancet Diabetes Endocrinol. 2016, 2, 125-135. [CrossRef]

26. Varadharajan, K.S.; Thomas, T.; Rajaraman, D.; Kurpad, A.V.; Vaz, M. Overweight and obesity among internal migrants in India. Asia Pac. J. Clin. Nutr. 2013, 3, 416-425.

27. Yang, H.; He, F.; Wang, T.; Liu, Y.; Shen, Y.; Gong, J.; Dai, W.; Zhou, J.; Gu, J.; Tu, Y.; et al. Health-related lifestyle behaviors among male and female rural-to-urban migrant workers in Shanghai, China. PLoS ONE 2015, 2. [CrossRef] [PubMed]

28. Shah, S.M.; Loney, T.; Sheek-Hussein, M.; El Sadig, M.; Al Dhaheri, S.; El Barazi, I.; Al Marzouqi, L.; Aw, T.C.; Ali, R. Hypertension prevalence, awareness, treatment, and control, in male South Asian immigrants in the United Arab Emirates: A cross-sectional study. BMC Cardiovasc. Disord. 2015, 15, 30. [CrossRef] [PubMed]

29. Castaneda, S.F.; Rosenbaum, R.P.; Holscher, J.T.; Madanat, H.; Talavera, G.A. Cardiovascular disease risk factors among Latino migrant and seasonal farmworkers. J. Agromed. 2015, 2, 95-104. [CrossRef] [PubMed]

30. Skokberg, N.; Laatikainen, T.; Jula, A.; Härkänen, T.; Vartiainen, E.; Koponen, P. Contribution of sociodemographic and lifestyle-related factors to the differences in metabolic syndrome among Russian, Somali and Kurdish migrants compared with Finns. Int. J. Cardiol. 2017, 232, 63-69. [CrossRef] [PubMed]

31. Shah, S.M.; Ali, R.; Loney, T.; Aziz, F.; El Barazi, I.; Al Dhaheri, S.; Farooqi, M.H.; Blair, I. Prevalence of Diabetes among Migrant Women and Duration of Residence in the United Arab Emirates: A Cross Sectional Study. PLOS ONE 2017, 1. [CrossRef] [PubMed]

32. Modesti, P.A.; Calabrese, M.; Malandrino, D.; Colella, A.; Galanti, G.; Zhao, D. New findings on type 2 diabetes in first-generation Chinese migrants settled in Italy: Chinese in Prato (CHIP) cross-sectional survey. Diabetes Metab. Res. Rev. 2017, 2. [CrossRef]

33. Yan, S.; Hong, X.; Yu, H.; Yang, Z.; Liu, S.; Quan, W.; Xu, J.; Zhu, L.; Cheng, W.; Xiao, H.; et al. Prevalence of Diabetes and Health-Related Quality of Life Among Rural-to-Urban Nong Zhuan Fei Migrants in an Urban Area of Northern China, 2013. Public Health Rep. 2016, 1, 167-176. [CrossRef]

34. Ronda, E.; Briones-Vozmediano, E.; Galon, T.; García, A.M.; Benavides, F.G.; Agudelo-Suárez, A.A. A qualitative exploration of the impact of the economic recession in Spain on working, living and health conditions: Reflections based on immigrant workers' experiences. Health Expect. 2016, 2, 416-426. [CrossRef]

35. Anjara, S.G.; Nellums, L.B.; Bonetto, C.; Van Bortel, T. Stress, health and quality of life of female migrant domestic workers in Singapore: A cross-sectional study. BMC Women's Health 2017, 1, 98. [CrossRef]

36. Lu, C.H.; Wang, P.X.; Lei, Y.X.; Luo, Z.C. Influence of health-related quality of life on health service utilization in Chinese rural-to-urban female migrant workers. Health Qual. Life Outcome 2014, 12, 121. [CrossRef] [PubMed]

37. Lu, L.; Zou, G.; Zeng, Z.; Han, L.; Guo, Y.; Ling, L. Health-Related Quality of Life and Its Correlates among Chinese Migrants in Small- and Medium-Sized Enterprises in Two Cities of Guangdong. PLoS ONE 2014, 9. [CrossRef] [PubMed]

38. Khongthanachayopit, S.; Laohasiriwong, W. Accessibility to health services among migrant workers in the Northeast of Thailand. F1000 Res. 2017, 6, 972. [CrossRef] [PubMed] 
39. Tam, W.J.; Goh, W.L.; Chua, J.; Legido-Quigley, H. Health is my capital: A qualitative study of access to healthcare by Chinese migrants in Singapore. Int. J. Equity Health 2017, 1, 102. [CrossRef] [PubMed]

40. Kumparatana, P.; Cournos, F.; Terlikbayeva, A.; Rozental, Y.; Gilbert, L. Factors associated with self-rated health among migrant workers: Results from a population-based cross-sectional study in Almaty, Kazakhstan. Int. J. Public Health 2017, 5, 541-550. [CrossRef]

41. Yang, H.; Gao, J.; Wang, T.; Yang, L.; Liu, Y.; Shen, Y.; Gong, J.; Dai, W.; Zhou, J.; Gu, J.; et al. Association between adverse mental health and an unhealthy lifestyle in rural-to-urban migrant workers in Shanghai. J. Formos. Med. Assoc. 2017, 2, 90-98. [CrossRef] [PubMed]

42. Bhandari, P.; Kim, M. Predictors of the Health-Promoting Behaviors of Nepalese Migrant Workers. J. Nurs. Res. 2016, 3, 232-239. [CrossRef] [PubMed]

43. Banerejee, M.; Kamath, R.; Tiwari, R.R.; Nair, N.P. Dermatological and respiratory problem in migrant construction workers of Udupi, Karnataka. Indian. J. Occup. Environ. Med. 2015, 3, 125-128. [CrossRef]

44. Perez-Carceles, M.D.; Medina, M.D.; Perez-Flores, D.; Noguera, J.A.; Pereniguez, J.E.; Madrigal, M.; Luna, A. Screening for hazardous drinking in migrant workers in southeastern Spain. J. Occup. Health 2014, 1, 39-48. [CrossRef]

45. Pichardo-Geisinger, R.; Muñoz-Ali, D.; Arcury, T.A.; Feldman, S.R.; Quandt, S.A. Dermatologist-diagnosed skin diseases among immigrant Latino poultry processors and other manual workers in North Carolina, USA. Int. J. Dermatol. 2013, 11, 1342-1348. [CrossRef] [PubMed]

46. Dodd, V.J.; Schenck, D.P.; Chaney, E.H.; Padhya, T. Assessing Oral Cancer Awareness among Rural Latino Migrant Workers. J. Immigr. Minor. Health 2016, 3, 552-560. [CrossRef] [PubMed]

47. Brumitt, J.; Garside, L.I.; Reisch, R.; Marshall, T.; Gilpin, H.E.; Kinsey, J.; Imondi, K.; Robinson, H.J. Exercise habits and tobacco use among male Latino farmworkers. Agromedicine 2013, 12, 122-131. [CrossRef] [PubMed]

48. Mendelsohn, J.B.; Calzavara, L.; Light, L.; Burchell, A.N. Design and implementation of a sexual health intervention for migrant construction workers situated in Shanghai, China. Emerg. Themes Epidemiol. 2015, 1. [CrossRef] [PubMed]

49. Sanchez, J.; De La Rosa, M.; Serna, C.A. Project Salud: Efficacy of a community-based HIV prevention intervention for Hispanic migrant workers in south Florida. AIDS Educ. Prev. 2013, 5, 363. [CrossRef] [PubMed]

50. Chen, W.; Li, T.; Zou, G.; Li, X.; Shi, L.; Feng, S.; Shi, J.; Zhou, F.; Han, S.; Ling, L. Study protocol: A cluster randomized controlled trial to assess the effectiveness of a multi-pronged behavioral intervention to improve use of personal protective equipment among migrant workers exposed to organic solvents in small and medium-sized enterprises. BMC Public Health 2016, 16, 580. [CrossRef]

51. Lee, H.; Cho, S.; Wilbur, J.; Kim, J.; Park, C.G.; Lee, Y.M.; Lee, H. Effects of culturally adaptive walking intervention on cardiovascular disease risks for middle-aged Korean-Chinese female migrant workers. Arch. Environ. Occup. Health 2017, 6, 317-327. [CrossRef] [PubMed]

52. Li, W.; Han, L.Q.; Guo, Y.J.; Sun, J. Using WeChat official accounts to improve malaria health literacy among Chinese expatriates in Niger: An intervention study. Malaria J. 2016, 1, 567. [CrossRef]

53. Vernier, M.; Rossi-Tamisier, M.; Richet, H.; Colson, P.; Gautret, P. Anti-hepatitis E virus antibody prevalence in French expatriate workers. IJID 2013, 11. [CrossRef]

54. Sharif, F.; Daryani, A.; Kia, E.; Rezaei, F.; Nasiri, M.; Nasrolahei, M. Prevalence of intestinal parasites among food handlers of Sari, Northern Iran. Rev. Inst. Med. Trop. Sao Paulo 2015, 2, 139-144. [CrossRef]

55. Kheirandish, F.; Tarahi, M.; Ezatpour, B. Prevalence of intestinal parasites among food handlers in West Iran. Rev. Inst. Med. Trop. Sao Paulo 2014, 2, 111-114. [CrossRef]

56. Wangroogsarb, P.; Hwang, J.; Thwing, J.; Karuchit, S.; Kumpetch, S.; Rand, A.; Drakeley, C.; MacArthur, J.R.; Kachur, S.P.; Satimai, W.; et al. Using Respondent Driven Sampling to Identify Malaria Risks and Occupational Networks among Migrant Workers in Ranong, Thailand. PLoS ONE 2016, 12. [CrossRef]

57. Global Tuberculosis Report 2018. Available online: https://www.who.int/tb/publications/global_report/ en/ (accessed on 30 October 2018).

58. Li, Y.; Huang, X.M.; Zhao, D.M.; Liu, Y.Z.; He, K.W.; Liu, Y.X.; Chen, C.H.; Long, L.P.; Xu, Y.; Xie, X.X.; et al. Detection of Avian H7N9 Influenza a Viruses in the Yangtze Delta Region of China during Early H7N9 Outbreaks. Avian Dis. 2016, 1, 118-125. [CrossRef] [PubMed] 
59. Leng, A.; Li, Y.; Wangen, K.R.; Nicholas, S.; Maitland, E.; Wang, J. Hepatitis B discrimination in everyday life by rural migrant workers in Beijing. Hum. Vaccines Immunother. 2016, 5, 1164-1171. [CrossRef] [PubMed]

60. Salyer, S.J.C.; Bron, C.; Juin, S.; Hemme, R.R.; Hunsperger, E.; Jentes, E.S.; Magloire, R.; Tomashek, K.M.; Desormeaux, A.M.; Muñoz-Jordán, J.L.; et al. Dengue virus infections among Haitian and expatriate non-governmental organization workers-Léogane and Port-au-Prince, Haiti, 2012. PLoS Negl. Trop. Dis. 2014, 10. [CrossRef] [PubMed]

61. Wang, D.; Tang, G.; Huang, Y.; Bai, T.; Shu, Y. A returning migrant worker with avian influenza A (H7N9) virus infection in Guizhou, China: A case report. J. Med. Case Rep. 2015, 9, 109. [CrossRef] [PubMed]

62. Ning, C.; Jiang, J.; Ye, L.; Yang, X.; Wei, B.; Deng, W.; Wei, S.; Huang, J.; Qin, B.; Upur, H.; et al. Comparison of Three Intervention Models for Promoting Circumcision among Migrant Workers in Western China to Reduce Local Sexual Transmission of HIV. PLoS ONE 2013, 9. [CrossRef]

63. Al Rifai, R.; Nakamura, K.; Seino, K.; Kizuki, M.; Morita, A. Unsafe sexual behaviour in domestic and foreign migrant male workers in multinational workplaces in Jordan: Occupational-based and behavioural assessment survey. BMJ Open 2015, 6. [CrossRef]

64. Norris, A.H.; Decker, M.R.; Weisband, Y.L.; Hindin, M.J. Reciprocal physical intimate partner violence is associated with prevalent STI/HIV among male Tanzanian migrant workers: A cross-sectional study. Sex Transm. Infect. 2017, 4, 253-258. [CrossRef]

65. Urmi, A.Z.; Leung, D.T.; Wilkinson, V.; Miah, M.A.A.; Rahman, M.; Azim, T. Profile of an HIV testing and counseling unit in Bangladesh: Majority of new diagnoses among returning migrant workers and spouses. PLoS ONE 2015, 10. [CrossRef]

66. Goldenberg, S.M.; Rocha Jiménez, T.; Brouwer, K.C.; Morales Miranda, S.; Silverman, J.G. Influence of indoor work environments on health, safety, and human rights among migrant sex workers at the Guatemala-Mexico Border: A call for occupational health and safety interventions. BMC Int. Health Hum. Rights 2018, 1, 9. [CrossRef]

67. Lee, W.S. Height, Weight and Well-Being for Rural, Urban and Migrant Workers in China. Soc. Indic. Res. 2017, 132, 117-136. [CrossRef]

68. Shah, S.M.; Loney, T.; Dhaheri, S.A.; Vatanparast, H.; Elbarazi, I.; Agarwal, M.; Blair, I.; Ali, R. Association between acculturation, obesity and cardiovascular risk factors among male South Asian migrants in the United Arab Emirates-A cross-sectional study. BMC Public Health 2015, 28, 204. [CrossRef]

69. Eastwood, S.V.; Tillin, T.; Dehbi, H.M.; Wright, A.; Forouhi, N.G.; Godsland, I. Ethnic differences in associations between fat deposition and incident diabetes and underlying mechanisms: The SABRE study. Obesity 2015, 3, 699-706. [CrossRef]

70. Gele, A.A.; Mbalilaki, A.J. Overweight and obesity among African immigrants in Oslo. BMC Res. Notes 2013, 6, 119. [CrossRef]

71. Martin, M.Y.; Francis, L.A. U.S. Migrant Networks and Adult Cardiometabolic Health in El Salvador. J. Immigr. Minor. Health 2016, 6, 1350-1356. [CrossRef] [PubMed]

72. Mannocci, A.; Pignalosa, S.; Nicosia, V.; Saulle, R.; Sernia, S.; La Torre, G. Cardiovascular Diseases Risk Factors in oil and gas workers: A ten years observational retrospective cohort. Annali di Igiene 2016, 2, 122-132. [CrossRef]

73. Norredam, M.; Agyemang, C.; Hoejbjerg Hansen, O.K.; Petersen, J.H.; Byberg, S.; Krasnik, A. Duration of residence and disease occurrence among refugees and family reunited immigrants: Test of the 'healthy migrant effect' hypothesis. Trop. Med. Int. Health 2014, 8, 958-967. [CrossRef]

74. Le-Scherban, F.; Albrecht, S.S.; Bertoni, A.; Kandula, N.; Mehta, N.; Diez Roux, A.V. Immigrant status and cardiovascular risk over time: Results from the Multi-Ethnic Study of Atherosclerosis. Ann. Epidemiol. 2016, 6, 429-435. [CrossRef]

75. Commodore-Mensah, N.; Ukonu, O.; Obisesan, J.K.; Aboagye, C.; Agyemang, C.M. Length of residence in the United States is associated with a higher prevalence of cardiometabolic risk factors in immigrants: A contemporary analysis of the National Health Interview Survey. J. Am. Heart. Assoc. 2016, 11. [CrossRef]

76. Adsul, B.B.; Laad, P.S.; Howal, P.V.; Chaturvedi, R.M. Health problems among migrant construction workers: A unique public-private partnership project. Indian. J. Occup. Environ. Med. 2011, 15, 29-32. [CrossRef]

77. Maldonado Molina, M.M.; Reingle, J.M.; Jennings, W.G.; Prado, G. Drinking and driving among immigrant and US-born Hispanic young adults: Results from a longitudinal and nationally representative study. Addict. Behav. 2011, 36, 381-388. [CrossRef] [PubMed] 
78. Relazione Annuale INAIL 2017. Available online: www.inail.it/cs/internet/comunicazione/pubblicazioni/ rapporti-e-relazioni-inail/relazione-annuale-anno-2017.html (accessed on 30 October 2018).

79. Biering, K.; Lander, F.; Rasmussen, K. Work injuries among migrant workers in Denmark. Occup. Environ. Med. 2017, 4, 235-242. [CrossRef] [PubMed]

80. Mariammal, T.; Jaisheeba, A.A.; Sornaraj, R. Work related respiratory symptoms and pulmonary function tests observed among construction and sanitary workers of Thoothukudi. Int. J. Pharm. Tech. Res. 2012, 4, 1266-1273.

81. Habib, R.R.; Mikati, D.; Hojeij, S.; Chaaya, M.; Zurayk, R. Associations between poor living conditions and multi-morbidity among Syrian migrant agricultural workers in Lebanon. Eur. J. Public Health 2016, 6, 1039-1044. [CrossRef] [PubMed]

82. Earle-Richardson, G.; Wyckoff, L.; Carrasquillo, M.; Scribani, M.; Jenkins, P.; May, J. Evaluation of a community-based participatory farmworker eye health intervention in the "black dirt" region of New York State. Am. J. Ind. Med. 2014, 9, 1053. [CrossRef]

83. Hsieh, Y.C.; Apostolopoulos, Y.; Sönmez, S. Work Conditions and Health and Well-Being of Latina Hotel Housekeepers. J. Immigr. Minor. Health 2016, 3, 568-581. [CrossRef]

84. Jensen, M.T.; Rundmo, T. Associations between work family conflict, emotional exhaustion, musculoskeletal pain, and gastrointestinal problems in a sample of business travelers. Scand. J. Psychol. 2015, 1, 105-113. [CrossRef]

85. Thomas, B.E.; Charles, N.; Watson, B.; Chandrasekaran, V.; Senthil Kumar, R.; Dhanalakshmi, A.; Wares, F.; Swaminathan, S. Prevalence of chest symptoms amongst brick kiln migrant workers and care seeking behaviour: A study from South India. J. Public Health 2015, 4, 590-596. [CrossRef]

86. Zeng, Z.; Lu, L.; Rao, Z.; Han, L.; Shi, J.; Ling, L. Analysis of use of personal protective equipment among rural-to-urban migrant workers in small and medium enterprises in Zhongshan and Shenzhen, China. Chin. J. Ind. Hyg. Occup. Dis. 2014, 4, 274-276.

87. Bener, A. Health status and working condition of migrant workers: Major public health problems. Int. J. Prev. Med. 2017, 8, 68. [CrossRef]

88. Dodd, W.; Humphries, S.; Patel, K.; Majowicz, S.; Little, M.; Dewey, C. Determinants of internal migrant health and the healthy migrant effect in South India: A mixed methods study. BMC Int. Health Hum. Rights 2017, 1, 23. [CrossRef] [PubMed]

89. Lu, C.; Luo, Z.; Wang, J.; Zhong, J.; Wang, P. Health-Related Quality of Life and Health Service Utilization in Chinese Rural-to-Urban Migrant Workers. Int. J. Environ. Res. Public Health 2015, 12, 2205-2214. [CrossRef] [PubMed]

90. Fan, W.; Qian, Y. Native-immigrant occupational segregation and worker health in the United States, 2004-2014. Soc. Sci. Med. 2017, 183, 130-141. [CrossRef] [PubMed]

91. Xing, H.; Yu, W.; Chen, S.; Zhang, D.; Tan, R. Influence of Social Support on Health-Related Quality of Life in New-Generation Migrant Workers in Eastern China. Iran J. Public Health 2013, 8, 806-812.

92. Chen, H.; Zhu, Z.; Sun, D.; Wang, X. The Physical and Psychological Health of Migrants in Guangzhou, China: How Does Neighborhood Matter? Inquiry 2016, 53. [CrossRef] [PubMed]

93. Di Fabio, A.; Bucci, O. Green positive guidance and green positive life counseling for decent work and decent lives: Some empirical results. Front. Psychol. 2016, 7, 261. [CrossRef] [PubMed]

(C) 2019 by the authors. Licensee MDPI, Basel, Switzerland. This article is an open access article distributed under the terms and conditions of the Creative Commons Attribution (CC BY) license (http:/ / creativecommons.org/licenses/by/4.0/). 